\title{
Determinants of Private Savings Effect on Economic Growth in Ethiopia
}

\author{
Dr. Ch. Venkata Krishna Reddy \\ Department of Accounting and Finance, College of Business and Economics, Salale University \\ Mr. Hailu Tesfaye \\ Department of Accounting and Finance, College of Business and Economics, Salale University
}

\begin{abstract}
Private saving is a very important factor in bringing economic development, its working or efficiency is determined by different socio economic and political factors. In Ethiopia, private saving does not have a deeprooted history because of frequent policy changes following the changes of government. The objective of this paper is to analyse the determinants of private saving in Ethiopia and also to check the long run or short run impact of real per capita GDP, real deposit interest rate, age dependency ratio, inflation rate and number of bank branches on private savings using time series annual data from 1978 to 2018. The research methodology employed are tests such as testing for stationery (unit root test) and co-integration test, rank of co-integration determined by using ARDL (Autoregressive- Distributed Lag) to characterize long-run and the short-run relationship between private saving and independent variables. The model is estimated by using Ordinary Least Square (OLS) and/or E-Views 10 also offered a specialized estimator for handling ARDL model. The estimated results revealed that real per capita GDP, real deposit interest rate, age dependency ratio and number of bank branches have found to be statistically significant and positive effect (but real per capita GDP negative in the short run) on private savings while inflation rate is found non-significant and negative effect on private savings in Ethiopia both in the long and short run periods in the study period. Based on the result, the researcher concluded that level of real per capita GDP and number of bank branches is found to be important variable and have very significant impact on private savings. Finally, the study recommended that the national level policy makers or decision makers has to take measure to improve income levels of society and special attention to increases financial access throughout the country by further expanding bank branches or other financial institutions and their services to increase private savings.
\end{abstract}

Keywords: Determinants of private savings, Economic growth, ARDL, co-integration, Ethiopia

DOI: $10.7176 / \mathrm{JPID} / 60-01$

Publication date:July $31^{\text {st }} 2021$

\section{Introduction}

National saving consists of two components which are public saving and private saving. In macroeconomic aspect, national saving is always assumed to be equal with total investment of the country. This assumption has implied that the amount of a country gross investment was influenced a lot by the amount of savings available in the country. Hence, this means that the higher the saving amount in a country, the larger the investment capacity of the country.

Mckinnon (1993) have suggested to the government to implement financial liberalization to encourage saving which will then enhance economic growth. Promoting economic growth through saving and investment has received considerable attention in many countries around the world (Vema, 2002). This is because high investment and saving rates are crucial for growth as a result of their strong positive correlation with GDP growth rates enunciated by endogenous growth theory (Agrawal, 2000). The conventional perception through which investment, savings and economic growth are related is the savings contribute to higher investment and hence higher GDP growth in the short run (Mohan, 2006).

Economic growth is the main target of all countries all over the world including both developed and developing countries. Among other things, rise in Gross Domestic Product (GDP) is a good indicator of economic growth; higher GDP implies higher income and thus higher standard of living. One of the important ingredients of GDP is saving. Therefore, most efforts to increase GDP and thus increase economic growth relay on saving. Private saving is a very important factor in bringing economic development, its working of efficiency is determined by different socio economic and political factors. Moreover, these different factors have different effects on private saving either in the negative or positive sense.

However there are different thoughts regarding linkages among this variables and how they affect one another. Thus, the government should identify potential determinant that were affect both public saving and private saving. This enable government to execute appropriate policy based on the determinant in order to increase saving. There are many different opinions arisen from past researches either by empirical results or theories when determining the potential determinants of private saving. There are also a few theories and 
hypothesis that give various opinions on determinants of private saving. Due to that, identification of determinants of private saving still remains ambiguous. Hence, it has cause a problem for policy makers in deciding the policy that used to increase private saving in a country.

In Ethiopia, private saving does not have a deep-rooted history because of frequent policy changes following the changes of government. The general trend of private saving as a percentage of GDP was falling after the year 1972/73. Ethiopia's private saving was lower in the Derg regime than the imperial era since it was above 10 percent before 1974 as compared to below 4 percent for the years 1973/74-1990/91. Despite its recovery in 1989/90, it fell again consistently and became negative for the year 1992/93. This is in spite of the introduction anew interest rate structure which resulted in positive real interest rate (WB, 2013).

Even in the present Ethiopian People's Revolutionary Democratic Front (EPRDF) government there is still a fluctuation over time though thereexists a significant change in private saving as compared to past times. And according to statistical reports a considerable proportion of total approved saving projects fail to be implemented due to several reasons in which many of them and attributed to the negative effects of determinants of private saving. Technology, higher employment, low level of poverty and others, which are the most common indicators of growth and development, are not yet attained in Ethiopian economy. And all these factors are related to saving where their long-term solutions can be reached through investment (Zewdu, 2006).

Similarly, according to the World Bank report (2011), the average saving rate of Ethiopia was very low compared with the averages of the sub-Saharan African countries. For instances, taking the data between the period 1980/81 and 2010/2011 show that average domestic saving rate of Ethiopia was only 8.6 percent of GDP. However, the average for Sub-Saharan African countries was 17.2 percent of GDP for the same period.This therefore indicates the need to boost savings in Ethiopia. Because of that, an understanding of the fundamental determinants of saving in Ethiopia represents critical importance in order to formulate policies to raise the domestic saving rate in line with the needs of economic growth.

Therefore, in order to study the effects of private saving on the performance of an economy, one needs to identify first, the factors that are affecting it. By doing so, the researcher could understand why and how changes in private saving occurred and possible correct prevailing problems of private saving by looking at the current situation of the determinants.

\section{Statement of the Problem}

Private saving is a very important factor in bringing economic development, its working or efficiency is determined by different socio economic and political factors. Moreover, these different factors have different effects on private saving either in the negative or positive sense. The role of savings in the promotion of economic growth and development in both developing and developed economies today had been noted by economists. Savings are very important in order to generate fund for investment (Ogbokor CA, Sanahiya OM, 2014).

Ethiopia is among the developing countries that need fast and sustainable increase in investment growth; however, the private domestic saving rate was on the lowest for several decades. The savings level in Ethiopia particularly in rural areas is very low and its patterns and determinants are not empirically identified. In rural areas in Ethiopia, savings is mainly made out of the income from agricultural produces, the flow of the income is irregular and seasonal which reduces the ability to save or poorly respond to the incentives which promote savings.

As indicated in the above background that private savings was lower in the Derge regime than the Imperial era. It fell again consistently and became negative for the year 1992/93. Even in the current government of Ethiopian People's Revolutionary Democratic Front (EPRDF) there is still a fluctuation over time though there exists a significant change in private saving as compared to past times. These statistics clearly support the need for improvement in domestic resource mobilization in the form of private savings in order to reduce foreign dependence since we know that private savings cover the biggest proportion of the total savings.

Moreover, during those periods domestic saving as a percent of GDP in Ethiopia shows improvements compared with earlier periods. For example, domestic saving to GDP in 1990's is 9.9 percent which is rise in to 11.2 percent in 2000's; it reaches 23.5 percent in 2015(National Bank of Ethiopia Annual report, 2016). In general saving trends indicates improvements but their growth is not consistent. It is also not impressive even when compared with in sub-Sahara African countries. This information clearly support the need for improvement in domestic resource mobilization in the form of private savings in order to reduce foreign dependence since we know that private savings cover the biggest proportion of the total savings.

Previous studies in case of Ethiopia i.e. Ayalew (1995) and Hadush (2012) did not use important variables in the saving model, which may have significant effect on private saving. There are a number of determinants of private saving which are not still well explained. This paper tries to fill this variable gap by incorporating important variables such as Age dependency ratio and number of bank branch. Besides to these variable gaps there is a research time gap in these areas. 
Therefore, this paper is also significant by filling the time gap using data's ranging from the year 19782018(40 years). As a result, the study is motivated by the basic questions raised in the following section to partially fill in the existing literature, time and variable gap by examining the determinants of private saving from the context of Ethiopia. Therefore, the central task of this paper is to analyse factors determining the private saving in Ethiopia for the period between 1978 and 2018 with methodology at hand.

\subsection{Research objectives}

\subsubsection{General Objective}

The general objective of this study is to identify the major determinants of private savings on Economic growth in Ethiopia using time series annual data from 1978 to 2018 and to give necessary recommendations.

\subsubsection{Specific objectives}

The study has the following specific objectives;

1. To examine the short-run and long-run effect of real per capita income GDP and private savings;

2. To analyse short-run and long-run effect of real deposit interest rate and private savings;

3. To investigate short-run and long-run effect of age dependency ratio and private savings;

4. To determine short-run and long-run effect of inflation rate and private savings;

5. To asses short-run and long-run effect of bank branches and private savings;

\subsection{Statement of Hypothesis}

This study uses the null and alternate hypothesis format. The null statements stand for no significant relationship whereas alternate expressed as significant relationship. Therefore, the following research hypothesis was checked.

1. $\mathrm{H}_{0}$ (Null Hypothesis): There is no significant relationship between real per capita income GDP and Private savings.

$\mathrm{H}_{1}$ (Alternative hypothesis): There is significant relationship between real per capita income GDP and Private savings.

2. $\mathrm{H}_{0}$ (Null Hypothesis): There is no significant relationship between real deposit interest rate and Private savings.

$\mathrm{H}_{1}$ (Alternative hypothesis): There is significant relationship between real deposit interest rate and Private savings.

3. $\mathrm{H}_{0}$ (Null Hypothesis): There is no significant relationship between age dependency ratio and Private savings.

$\mathrm{H}_{1}$ (Alternative hypothesis): There is significant relationship between age dependency ratio and Private savings.

4. $\mathrm{H}_{0}$ (Null Hypothesis): There is no significant relationship between Inflation rate and Private savings.

$\mathrm{H}_{1}$ (Alternative hypothesis): There is significant relationship between Inflation rate and Private savings.

5. $\mathrm{H}_{0}$ (Null Hypothesis): There is no significant relationship between number of Bank branches and Private savings.

$\mathrm{H}_{1}$ (Alternative hypothesis): There is significant relationship between number of Bank branches and Private savings.

\subsection{Significance of the Study}

The assumptions of the inter-temporal saving function may not be realistic for developing countries and for Ethiopia. According to Angus Deaton (1989) saving in developing countries should be studied separately as compared with developed countries. This is because households in developing countries are large and poor and most of their earnings depend on agricultural sector, which implies that they are likely to face higher uncertainty than advanced countries. In addition to this they have a different demographic structure and which is expected to encounter liquidity constraints.

Therefore, this study was informed to the stakeholders in the society about the real picture of the determinants of private saving on Ethiopian economic growth by analysing the different factors that affects savings. The study focused on:

$\checkmark$ To provide an empirical evidence on the determinant of private saving on economic growth.

$\checkmark$ To test the significant changes in the variables that affects savings.

$\checkmark$ This also useful to the future studies in this field for the further researchers.

\subsection{Scope of the Study}

The aim of this study was limited to examine the short-run and long-run effect of private savings on economic growth in Ethiopia using yearly data starting from 1978 to 2018. The data obtained from Central Statistics 
Agency, National Bank of Ethiopia, Commercial Banks, Ethiopian Investment offices, Ministry of Finance and Economic Cooperation, Ethiopian Economic Associations, Books, Journals, Published and unpublished papers, websites and so on. The period is chosen on the basis of the availability of reliable data. More importantly, the study limited on major determinant variables of level of real per capita GDP, Consumer price index (Inflation), Real Interest rate, age dependency ratio and number of Bank branches.

\subsection{Research Design}

The type of the research design for this study is inferential in nature since it is an explanatory study on the determinants of saving in Ethiopia. Quantitative method is employed by the researchers as the empirical assessments consist of numerical measurement and analysis. In the perspective of time horizon, 40 years data collected from 1978 to 2018. The researcher follow a deductive approach by conducting the research based on existing theories and researches (Saunders, Lewis \&Thornhill, 2009) to test the relationship between private savings and the determinants (real per capita GDP, real deposit interest rate, age dependency ratio, inflation rate and the number of bank branches).

\subsection{Research Approach}

As a time series data was used for all variables in this research. The researcher for this study applied quantitative research design to collect necessary and enough information about the determinants of private saving on economic growth in Ethiopia, for the quantitative method, research was used survey, in which some data expressed as a natural logarithm and some are in their growth rate.

\subsection{Research Methodology}

Depending on the nature of the problem and the purpose of this study, the researcher uses inferential statistics to see the determinants of private saving on economic growth in Ethiopia by using econometrics models.

As the data used is time series, various tests such as testing for stationery (unit root test) and co-integration test are performed. The rank of co-integration is determined by using ARDL (Autoregressive- Distributed Lag). The model is estimated by using Ordinary Least Square (OLS) and/or E-Views also offer a specialized estimator for handling ARDL model. This estimator offers built in lag-length selection methods, as well as post estimation views.

\subsection{Research Techniques}

The study collected data on real per capita GDP (RPCGDP), real deposit interest rate (RDIR), age dependency ratio (ADR), inflation rate (IFR) and number of bank branches (NBB) using reports and documents from different government and non-government organizations.

\subsection{Population or Target Population}

The population from which the time series data of the variables are taken from the period starting 1978 up to 2018(40 years), and the study is conducted by taking the whole portion of the population as a sample.

\subsection{Method of Data collection}

The researcher has conducted this study on a survey, using secondary data. Secondary data was gathered from documentation mainly on annual reports of government institutions such as Central Statistics Agency (CSA), National Bank of Ethiopia (NBE), Commercial Banks, Ethiopian Investment offices (EIO), Ministry of Finance and Economic Cooperation (MoFEC), Ethiopian Economic Associations (EEA), and the like.

\subsubsection{Source of Data}

The study mainly uses secondary data of Journal articles, reviews, academic books, Annual reports, Published and unpublished papers, websites and so on. The source of data for GDP, per capita GDP, private savings, and real deposit rate of interest, inflation rate and number of Bank branches was obtained from National Bank of Ethiopia (NBE), Commercial Banks, Ministry of Finance and Economic Cooperation (MoFEC). For Ethiopian economy analysis and social indicators data was obtained from National Bank of Ethiopia (NBE) and Ethiopian Economic Associations (EEA). Data such as age dependency ratio was taken from Central Statistics Agency (CSA) and National Bank of Ethiopia (NBE). The data that researcher collect to conduct this study is time series data and the year ranges from year 1978 to 2018(40 years).

\subsection{RESULT AND DISCUSSION}

\subsubsection{Descriptive Analysis}

Descriptive analysis is the term given to the analysis of data that helps to describe, show or summarize data in a meaningful way. In other word, descriptive analysis is used to describe the basic features of the data and also to determine the normality of the distribution. For this reason it was conducted by using graphs for each variable to 
detect the movements in the value of each variable over time and to analyse the causes of such movements.

Figure1: Trends for Growth rate of private saving

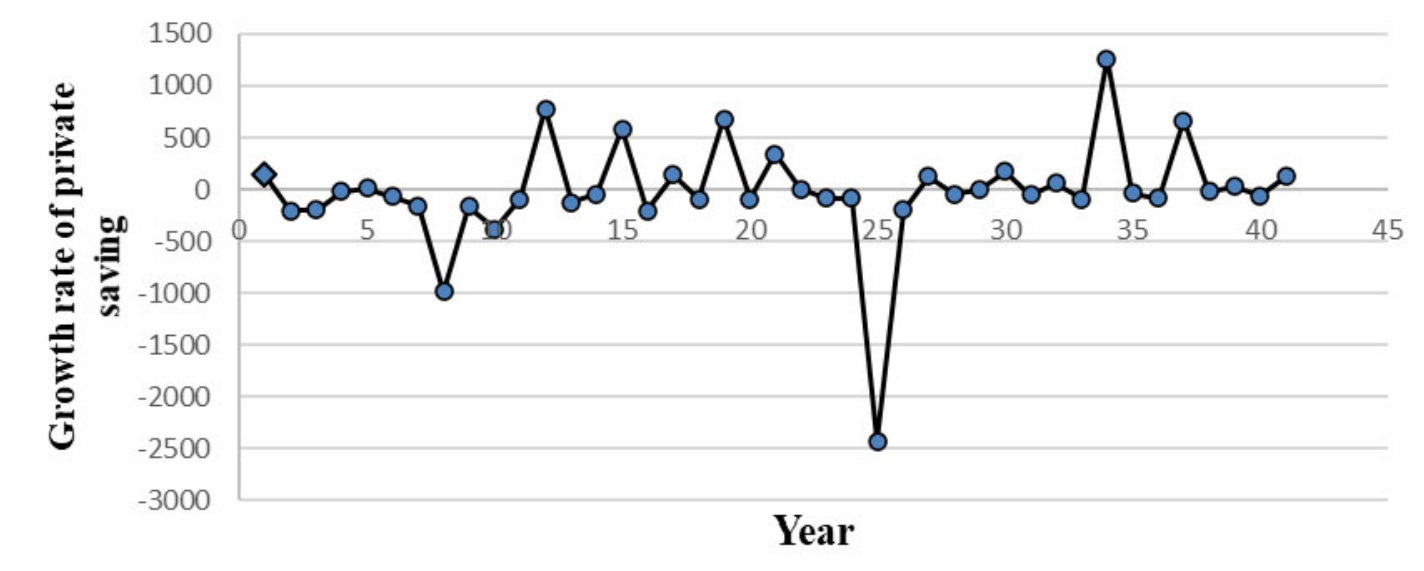

Source: Own sketch with Data from National Bank of Ethiopia, 2020.

The poor performance of the private saving rate, as shown in figure1, was mainly due to the exclusive control of economic activity by the government until early 1990s while, following the regime change in 1991/92 many macroeconomic reforms have been taken place; of which adoption of market economic policy, privatization of public enterprises, financial sector reforms including the opening of private banks, insurance companies and microfinance institutions are among the majors. As a result, the private saving rate increased on average by 24.5 percent from 1993/94 to 2017/18 and showed continuous rise, especially from 2008/09 onwards.

As figure-1indicates that there is a sharp decline in growth rates during 1986, this is because during this period there was a wide spread famine in Gojjam, Hararghe, Tigray, and Wollo caused by shortage of rain fall, after this period it starts to show a little improvements but it show a decline in 1990/91 and 1991/92 following the regime changes in the countries.

In $2002 / 03$, the country was under fire due to the wide spread drought that led to food insecurity for over more than 14 million persons (United States Agency for International Development, 2003).

Therefore, from figure-1 above, we found that the growth rate of private savings in Ethiopia has a volatile trend in each year. This might be related to the poor performance of saving behaviour in the people and inadequate fiscal policy implementation by the Government, the amount of saving in the country is very low.

Figure-2: Trends of Real GDP per capita Growth rate

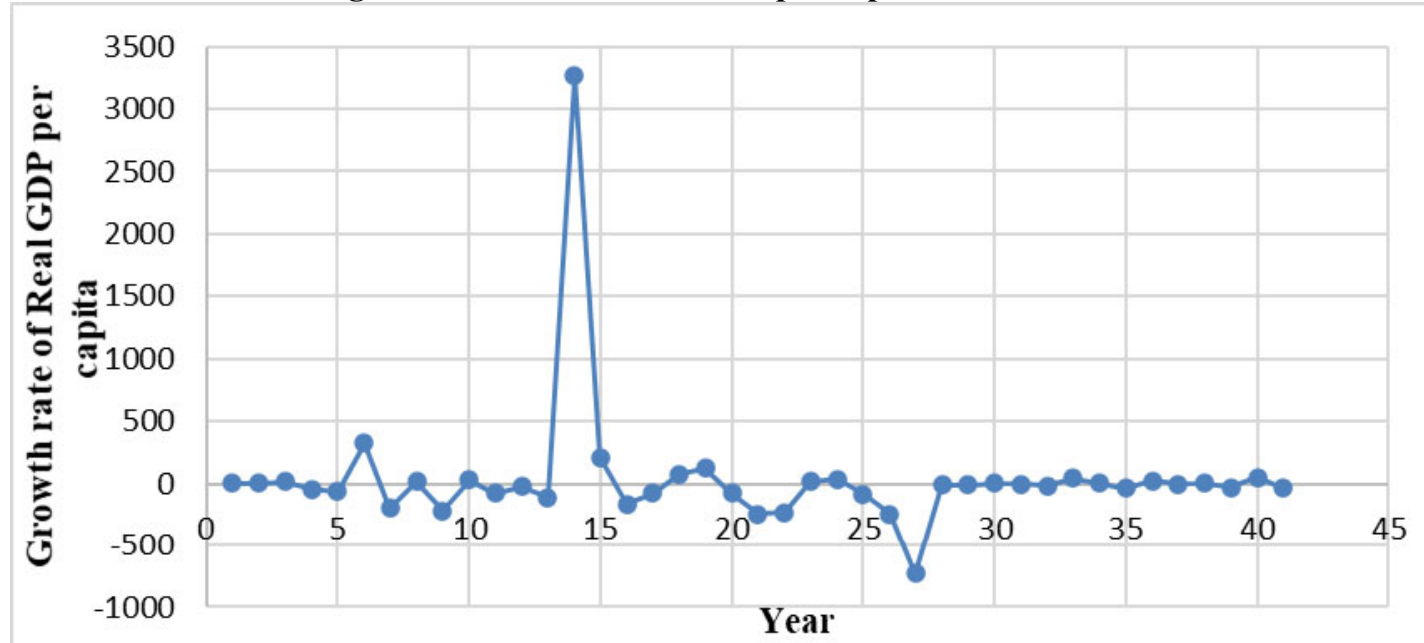

Source: Own sketch with Data from National Bank of Ethiopia, 2020.

Contribution to GDP growth rate in Ethiopian economy is mainly attributed by Agriculture, Industry and Services sectors growth rate. Since real GDP per capita has depend on GDP growth rate, the growth rate of Agriculture, Industry and Service sectors are also affected real per capita income.

Figure-2 above depicts that real GDP per capita growth rate in Ethiopia registers many ups and downs during the sample periods. As the country's economy is highly dependent on agriculture, much of the fluctuations in real GDP growth rate have been due to variation in rainfall and climatic condition that affects agricultural production as the economy is highly dependent on agriculture.

As the figure indicates that there is a sharp increase in growth rate during 1992/93 this is because following 
the regime changes in the country. Contrary to this, the lowest growth rate was register during 2004/05, and the period was the second national election process and during the period there was political instability in the country.

Figure-3: Trends of private saving rate and real GDP per capita Growth rate

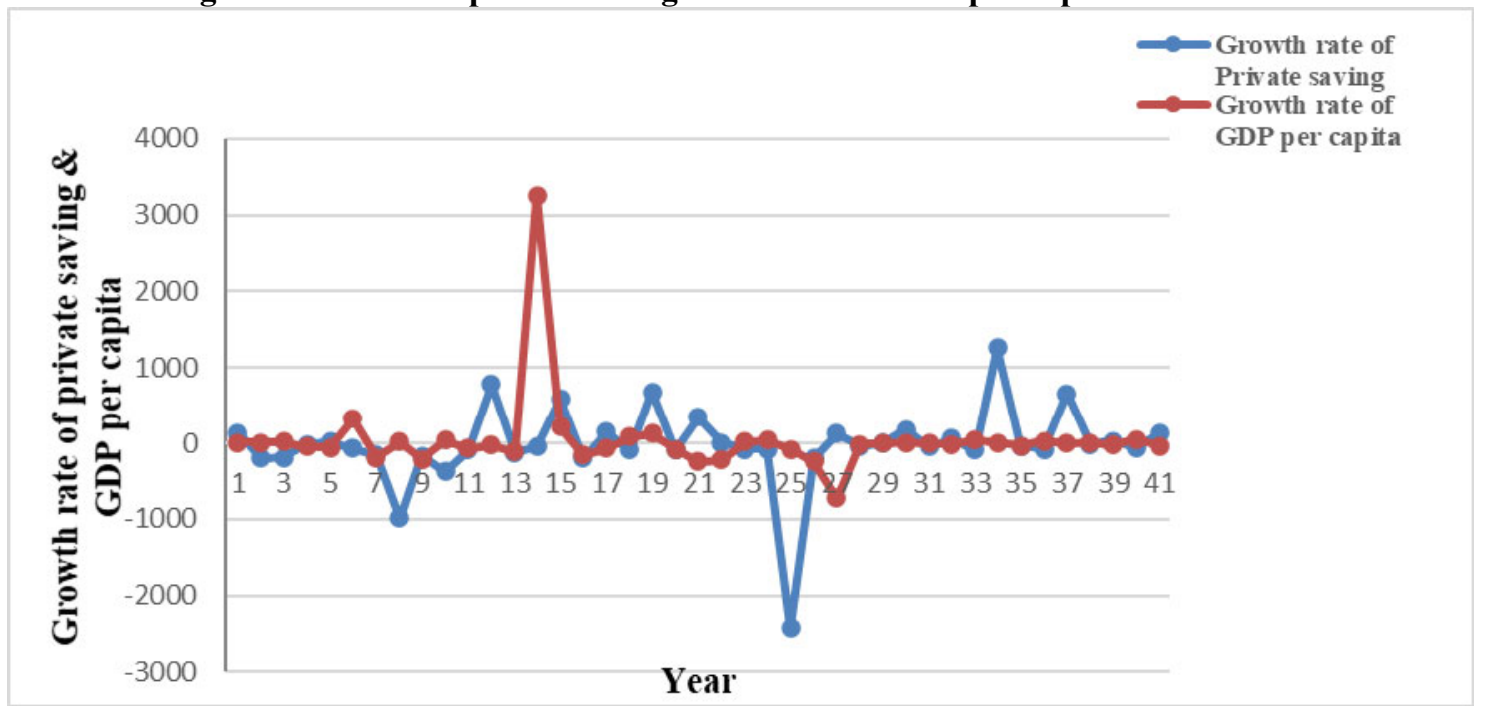

Source: Own sketch with Data from National Bank of Ethiopia, 2020.

The above figure-3 shows trends of private saving rate and Real GDP per capita growth rate during the sample periods. Accordingly, both private savings and real GDP per capita has shown a volatile growth rate trends in the study periods. In other words, the figure demonstrates that the growth rate trend of private savings and real GDP per capita are converges in many years of the study periods.

Therefore, the above figure result indicates that private saving is depend on real GDP per capita, implies that the growth of real GDP per capita is affecting the growth of private saving. Moreover, the figure indicates a positive two-way relationship between income and saving rates and this relationship is also consistent with Keynesian consumption theory, which suggests that the higher the income, the higher the marginal propensity to save.

Figure-4: Trends in Real Deposit interest rate and Inflation rate

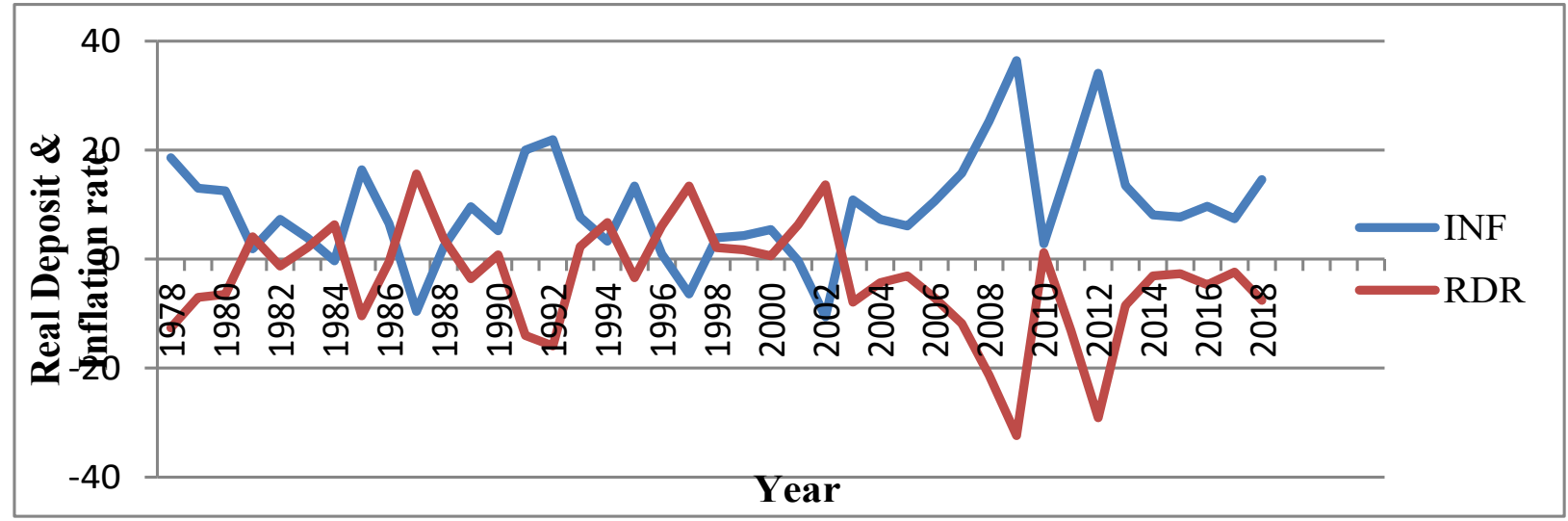

Source: Own sketch with Data from National Bank, 2020.

Figure-4 above shows that the real deposit rate is negative in most of the study period. It also shows that trends in real deposit rate of interest and inflation rate have been a mixture of high and low movements in opposite direction for the entire study period. It also shows that the years when the real interest rate reach its least, coincided with those of the highest double-digit inflation rates. For instance, the sharpest decline of real interest rate (32.4 percent) occurred when inflation rate reached the highest (36.4 percent) in 2008/09. The nominal interest rate was fixed at 6 percent during the dergue regime and becomes double digit for the next five consecutive years leading real deposit rate to be positive reach (6.1 percent) in 1995/96. Thereafter, the real deposit rate shows ups and downs and it becomes almost negative in the past ten years following the rise in inflation rate during the period besides the lowest nominal rate. Therefore, the movement of the real deposit interest rate follows the opposite movement of the inflation rate may imply that the nominal interest rate was institutionally determined by the monetary authorities throughout the study period. 
In general, from the above four figures and analysis, the amount of saving in the country was volatile and very low due to poor performance of saving behaviour in the country and inadequate fiscal policy implementation by the government. Similarly, the trends of real GDP per capita found to be variability throughout the study periods. Growth rate of private saving and real GDP per capita were converged and are positively related each other. Real deposit interest rate and general inflation rates were moved in opposite direction, which implies that nominal interest rate was regulated by the government in order to reduce inflation rate.

\subsection{Estimation Techniques}

\subsubsection{The Unit Root Test Analysis}

When estimating a model that includes time series variables, it is necessary to ensure that all time series variables in the model are stationary, which means that they are integrated of the same order. This is done by conducting a unit root test on each variable to find the order of integration. In order to determine the degree of integration, a unit root test was carried out using the standard Augmented Dickey Fuller (ADF) and PhillipsPerron test statistic (PP) test. Moreover, in applying ARDL model, all the variables entered in the regression should not be integrated of order two. To check these conditions, unit root test was conducted before any sort of action taken. Even though the ARDL framework does not require pretesting variables to be done, the unit root test could convenience us whether or not the ARDL model should be used. An I $(0)$ series is a time series that is stationary at level. An I(1) series contains one unit root and is a time series that is stationery at first difference. The result in Table-1 shows that there is a mixture of $\mathrm{I}(0)$ and $\mathrm{I}(1)$ but not any order two.

Table-1: Unit Root Test (Augmented Dickey Fuller Test)

\begin{tabular}{|c|c|c|c|c|c|}
\hline \multirow{2}{*}{ Variables } & \multicolumn{2}{|c|}{ With constant only } & \multicolumn{2}{|c|}{ with constant and trend } & \multirow{2}{*}{$\begin{array}{c}\text { Order of } \\
\text { integration }\end{array}$} \\
\hline & t-statistics & critical values & t-statistics & critical values & \\
\hline LNPS & -7.558 & -2.939 & -7.835 & -3.529 & $\mathrm{I}(1)$ \\
\hline LN(RPCGDP) & -8.525 & -2.941 & -8.677 & -3.533 & $\mathrm{I}(1)$ \\
\hline LN(RDIR) & -6.053 & -2.936 & -6.168 & -3.526 & $\mathrm{I}(0)$ \\
\hline LN(ADR) & -5.854 & -2.939 & -6.189 & -3.529 & $\mathrm{I}(1)$ \\
\hline INFR & -4.358 & -2.936 & -4.619 & -3.526 & $\mathrm{I}(0)$ \\
\hline LN(BB) & -2.300 & -2.939 & -3.859 & -3.529 & $\mathrm{I}(1)$ \\
\hline Dtdummy & -4.024 & -2.943 & -3.891 & -3.536 & $\mathrm{I}(1)$ \\
\hline
\end{tabular}

Note: The rejection of the null hypothesis is based on MacKinnon (1996) critical value. Schwarz information criterion (SIC) is used to determine the lag length while testing the stationerity of all variables.

$1 \%$ Critical Value *-3.6117, 5\% Critical Value *-2.9399, 10\% Critical Value*-2.608

*MacKinnon critical values for rejection of hypothesis of a unit root

Source: Results of Eviews-10, 2020.

As we have seen from table-1 of ADF test result; private saving(PS), level of real per capita GDP(RPCGDP), age dependency ratio(ADR), and number of bank branch(NBB) are integrated of order one(I(1)) while real deposit interest rate(RDIR) and inflation(IFR) are integrated of order zero(I(0)) at $1 \%$ level of significance. Meaning the t-statistics value of private saving(7.835), level of real per capita GDP(8.677), age dependency ratio(6.189) and number of bank branch(3.859) is larger than its critical value of $3.529 ; 3.533 ; 3.529$ and 3.529 under constant and trend condition, respectively at first difference. Similarly, the t-statistics value of real deposit interest rate (6.189) and inflation rate (4.619) is larger than its critical value of 3.526 under constant and trend condition, respectively in level.

Table-2: Unit Root Test (Phillips-Perron Test)

\begin{tabular}{|l|c|c|c|c|c|}
\hline \multirow{2}{*}{ Variables } & \multicolumn{2}{|c|}{ With constant only } & \multicolumn{2}{c|}{ with constant and trend } & $\begin{array}{c}\text { Order of } \\
\text { integration }\end{array}$ \\
\cline { 2 - 5 } & t-statistics & $\mathbf{5 \%}$ critical values & t-statistics & $\mathbf{5 \%}$ critical values & I(1) \\
\hline LNPS & -7.470 & -2.939 & -8.577 & -3.529 & $\mathrm{I}(1)$ \\
\hline LN(RPCGDP) & -12.37 & -2.939 & -17.507 & -3.529 & $\mathrm{I}(0)$ \\
\hline LN(RDIR) & -6.050 & -2.936 & -7.805 & -3.526 & $\mathrm{I}(1)$ \\
\hline LN(ADR) & -5.853 & -2.939 & -6.203 & -3.529 & $\mathrm{I}(0)$ \\
\hline INFR & -4.372 & -2.936 & -4.585 & -3.526 & $\mathrm{I}(1)$ \\
\hline LN(BB) & -2.082 & -2.939 & -3.854 & -3.529 & $\mathrm{I}(1)$ \\
\hline Dtdummy & -9.842 & -2.939 & -9.601 & -3.529 & \\
\hline
\end{tabular}

Note: The rejection of the null hypothesis is based on MacKinnon (1996) critical value. Schwarz information criterion (SIC) is used to determine the lag length while testing the stationerity of all variables.

$1 \%$ Critical Value *-3.6117, 5\% Critical Value *-2.9399, 10\% Critical Value*-2.608

*MacKinnon critical values for rejection of hypothesis of a unit root

Source: Results of Eviews-10, 2020. 
Similarly, the results for unit root test of PP in table-2 concurs with those obtained from ADF test where the null hypothesis in PP test of private saving (PS), level of real per capita GDP (RPCGDP), age dependency ratio (ADR), and number of bank branches (NBB) are non-stationery at level, however taking the first difference of the variables makes them stationery since the null hypothesis of unit root is rejected at $1 \%$ level of significance. Whereas real deposit interest rate (RDIR) and inflation (IFR) are stationery in level at $1 \%$ level of significance. Meaning the t-statistics value of private saving (8.577), level of real per capita GDP (17.507), age dependency ratio (6.203) and number of bank branch (3.854) is larger than their critical value of 3.529 under constant and trend condition, respectively at first difference. Similarly, the t-statistics value of real deposit interest rate (7.805) and inflation rate (4.585) is larger than its critical value of 3.526 under constant and trend condition, respectively in level.

\subsubsection{Model Stability and Diagnostic Test}

To check the verifiability of the estimated long-run model, some diagnostic test is undertaken. Priority in doing any analysis, we required checking the standard property of the model. In this study, we carried a number of model stability and diagnostic checking, which includes Serial correlation test (Breusch\& Godfrey LM test), Functional form (Ramsey's RESET) test, Normality (Jaque-Bera test), and Heteroscedasticity test. In addition to the above diagnostic tests, the stability of long-run estimates has been tested by applying the cumulative sum of recursive residuals (CUSUM) and the cumulative sum of squares of recursive residuals (CUSUMSQ) test. Such tests are recommended by Pesaranet el. (2001). In order to reject or accept the null hypothesis, we can decide by looking the p-values associated with the test statistics. That is the null hypothesis is rejected when the p-value is smaller than the standard significance level (I.e. $5 \%$ )

Table-3: Diagnostic Test for the Long run ARDL $(1,3,0,0,0,1)$

\begin{tabular}{|l|c|c|}
\hline \multicolumn{1}{|c|}{ Test Statistics } & LM Version & F-Version \\
\hline A. Serial Correlation & $\mathrm{CHSQ}(1)=1.280578[0.2578]$ & $\mathrm{F}(1,33)=1.063940[0.3098]$ \\
\hline B. Functional Form & $\mathrm{CHSQ}(25)=0.63459[0.5315]$ & $\mathrm{F}(1,25)=0.402705[0.5315]$ \\
\hline C. Normality & {$[0.592495]$} & {$[0.743603]$} \\
\hline D. Heteroscedasticity & $\mathrm{CHSQ}(6)=9.555908[0.1446]$ & $\mathrm{F}(6,34)=1.722109[0.1458]$ \\
\hline \multicolumn{2}{|c|}{$\mathrm{R}^{2}=0.862279 \quad$ Adjusted $\mathrm{R}^{2}=0.833065$} & $\mathrm{DW}=2.527590$ \\
A: Breusch- Godfrey serial correlation LM Test & \\
B: Ramsey's RESET test using the square of the fitted values & \\
C: Based on Jaque- Berra normality test & \\
D: Based on the regression of squared residuals on squared fitted values & \\
\hline
\end{tabular}

Source: Results of Eviews-10, 2020.

The above table indicates that the long run ARDL model estimated in this study passes all the diagnostic tests. This is because the p-value associated with both the LM version and the F version of the statistic was unable to reject the null hypothesis specified for each test. Therefore, based on the result of the test:

(A) The null hypothesis of no serial correlation(Breusch\& Godfrey Serial Correlation LM test) is failed to reject for the reason that the p-values associated with test statistic are greater than the standard significant level(I.e. $0.2578>0.05$ ). Her LM test for testing serial correlation is applied because unlike the traditional Durbin Watson test statistic which is totally inapplicable when the lagged dependent variable appears as regressors, LM test avoid such limitation of DW test.

(B) We could not reject the null hypothesis test for Ramsey's RESET test, which tests whether the model suffers from omitted variables bias or not. As the test result indicates that we can't reject Ramsey's test, which means that the model is correctly specified (I.e. $0.5315>0.05$ ).

(C) The third diagnostic test is about the residual test. As the result indicates that we could not reject the null hypothesis which says that the residuals are normally distributed, for the reason, that the p-value associated with the Jaque-Berra normality test is larger than the standard significance level (I.e. $0.592495>0.05$ ).

(D) The last diagnostic test is for heteroscedasticity test. As we have seen from the above table, we can't reject at $5 \%$ significant level due to its p-value associated with the test statistics are greater than the standard significance level $(0.1446>0.05)$.

Moreover, the stability of the model for the long run and short run relationship is detected by using the cumulative sum of recursive residuals (CUSUM) and the cumulative sum of squares of recursive residuals (CUSUMSQ) tests. The test finds serious parameter instability of the cumulative sum goes outside the area (never returns back) between the two critical lines. 
Figure-5: Testing Parameter Stability using CUSUM and CUSUMSQ Test-Plot of Cumulative Sum of Recursive (A)

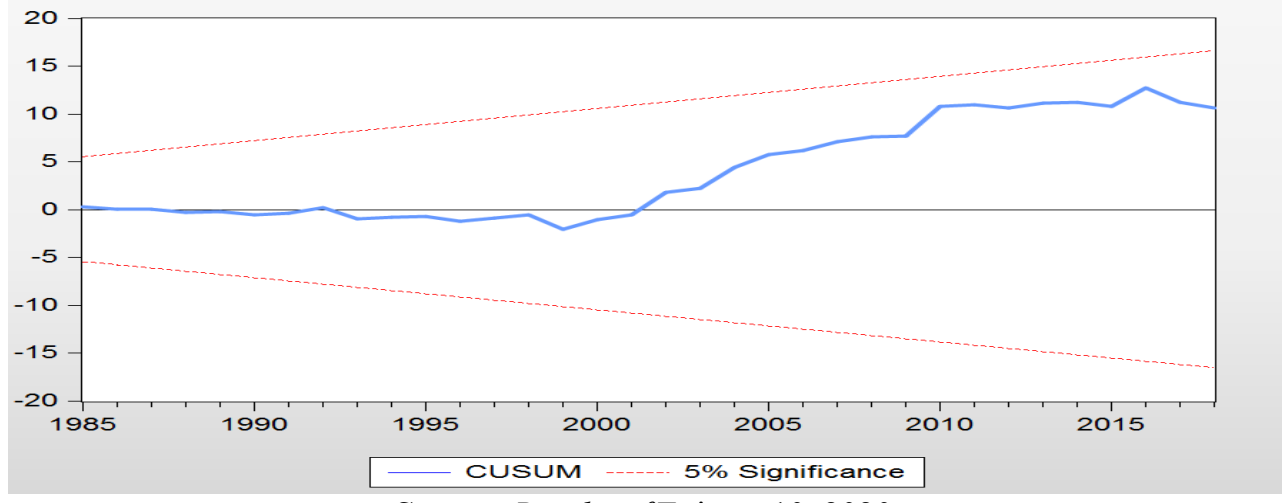

Source: Results of Eviews-10, 2020.

Figure-6: Testing Parameter Stability Using CUSUM and CUSUMSQ Test-Plot of Cumulative Sum of Recursive(B)

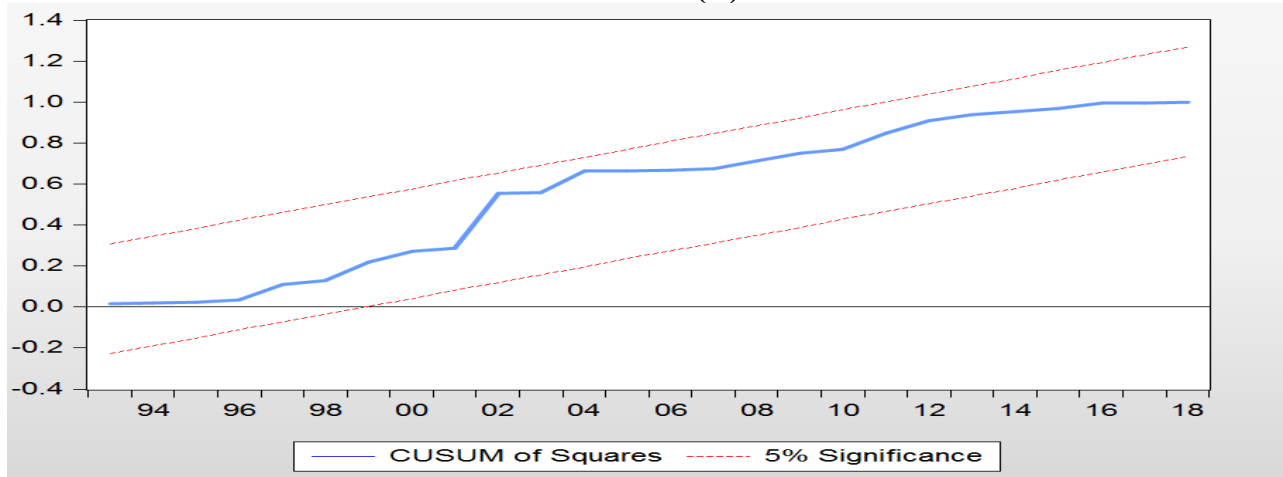

Source: Results of Eviews-10, 2020.

The straight line represents critical bounds as 5\% significance level.

As can be seen from the first figure-5, the plot of CUSUM test did not cross the critical limits. Similarly, the CUSUMSQ figure6) test shows that the graphs do not cross the lower and upper critical limit. So, we can conclude that long-run estimates are stable and there is no any structural break. In addition to the model stability, $83.3 \%$ of the model has been explained by the regressors. Hence the results of the estimated model are reliable and efficient.

\subsubsection{Long Run ARDL Bounds Tests for Co-integration}

This part of the study answers the hypothesis stated in the research hypothesis number one of chapter one that whether there is no significant relationship or there is significant relationship between the determinants and private savings.

Since as determined the stationery nature of the variables, the next task in the bounds test approach of cointegration is estimating the ARDL model specified in equation(4) using the appropriate lag-length selection criterion. A lag length that minimizes AIC is 3 . In addition to this, we have also used AIC to determine the optimal lag because is a better choice for smaller sample size data as this study.

Selection of appropriate lag length using proper information criterion such as Final prediction error (FPE), Akaike information criterion (AIC), Schwarz information criterion (SC) and Hannan - Quinn information (HQ) were employed and the results are presented in table 4.

Table-4: Lag Order Selection for Estimated Model

\begin{tabular}{|c|r|r|r|r|r|r|}
\hline Lag & \multicolumn{1}{|c|}{ LogL } & \multicolumn{1}{|c|}{ LR } & FPE & \multicolumn{1}{|c|}{ AIC } & \multicolumn{1}{|c|}{ SC } & HQ \\
\hline $\mathbf{0}$ & -213.25 & NA & 0.005676 & 11.85512 & 12.37225 & 12.03911 \\
\hline $\mathbf{1}$ & -50.204 & 257.436 & $7.35 \mathrm{E}-06$ & 5.168655 & $7.237185^{*}$ & 5.904622 \\
\hline $\mathbf{2}$ & 7.9284 & 73.43096 & $2.75 \mathrm{E}-06$ & 4.003769 & 7.623696 & 5.291711 \\
\hline $\mathbf{3}$ & 68.23636 & $57.13386^{*}$ & $1.24 \mathrm{e}-06^{*}$ & $2.724402^{*}$ & 7.895727 & $4.564320^{*}$ \\
\hline
\end{tabular}

Source: Results of Eviews-10, 2020.

Note: '*' indicate lag order selected by the VAR criterion. LR: Sequential LR test statistics (each test at 5\%).FPE: Final prediction error, AIC: Akaike information criterion, SC: Schwarz information criterion. '*' also indicate lowest LR, FPE, AIC, SC and HQ value. 
According to the rule of thumb for choosing the appropriate lag length, the lag with the smallest LR, FPE, AIC, SC and HQ value should be chosen. From table-4.4above, the lag with the smallest LR, FPE, AIC and HQ value is lag 3 which contain the value of 57.13386, 1.24e-06, 2.724402 and 4.564320 respectively. Hence, favourable lag length selected in this analysis is 3 at which is selected by most information criterions.

As we discuss in the third part of this study (Co-integration test), the F-test through the Wald-test (bound test) is performed to check the joint significance of the coefficients specified in equation (5). The Wald test is conducted by without imposing restrictions on the estimated long-run coefficients of private saving (PS), level of real per capita income GDP (RPCIGDP), real deposit interest rate (RDIR), age dependency ratio (ADR), inflation (IFR) and Number of bank branch (NBB). The computed F-statistic value is compared with the lower bound and upper bound critical values provided by Pesaranet al. (2001) and Narayan (2005).

\section{Table-5: Calculated F-Statistic}

\begin{tabular}{|c|c|c|}
\hline Number of observation & Lag Length & Value of Calculated F-Statistic \\
\hline 40 & 5 & 8.41446 \\
\hline
\end{tabular}

Source: Results of Eviews-10, 2020.

As we have seen from the above table the calculated F-statistic is strongly significant at 1 percent significance level.

Table-6: The Upper and Lower Critical Values

\begin{tabular}{|c|c|c|c|c|}
\hline \multirow{3}{*}{ Critical value } & \multicolumn{2}{|c|}{ Pesaran et al.(2001) } & \multicolumn{2}{c|}{ Narayan(2005) } \\
\cline { 2 - 5 } & $\begin{array}{c}\text { Lower Bound Value } \\
\mathrm{I}(0)\end{array}$ & $\begin{array}{c}\text { Upper Bound Value } \\
\mathrm{I}(1)\end{array}$ & $\begin{array}{c}\text { Lower Bound Value } \\
\mathrm{I}(0)\end{array}$ & $\begin{array}{c}\text { Upper Bound Value } \\
\mathrm{I}(1)\end{array}$ \\
\hline $1 \%$ & 3.41 & 4.68 & 5.198 & 6.845 \\
\hline $5 \%$ & 2.62 & 3.79 & 3.615 & 4.913 \\
\hline $10 \%$ & 2.26 & 3.35 & 2.958 & 4.100 \\
\hline
\end{tabular}

Source: Pesaran, Shine, and Smith (2001) and Narayan (2005) tables and results of Eviews-10, 2020.

The critical values reported for Pesaranet el.(2001) and Narayan(2005) are the case with unrestricted intercept and no trend(CI(iii) case III). As it is depicted in table-4.5and table-4.6above, with an intercept and no trend, the calculated F statistics (8.41446) is higher than both the Pesaranet el.(2001) and Narayan(2005) upper bound critical values at $1 \%$ level of significance. This implies that the null hypothesis of no long-run relationship is rejected; rather accept the alternative hypothesis (there is a long-run relationship) based on the Pesaranet el. (2001) and Narayan (2005) critical values at 1\% level of significance. Therefore, there is a co-integration relationship between the variables in long-run.

\subsubsection{Long Run ARDL Model Estimation}

After confirming the existence of a long-run co-integration relationship among the variables, the next step is running the appropriate ARDL model to find out the long run coefficients, which is reported in table-7 below.

Table-7: Estimated Long run coefficients using the ARDL Approach ARDL (1, 3, 0, 0, 0,1) selected based on Akaike Information Criterion

\begin{tabular}{|l|c|c|c|c|}
\hline \multicolumn{5}{|c|}{ Dependent Variable is PS } \\
\hline \multicolumn{1}{|c|}{ Regressors } & Coefficient & Standard Error & t-Statistic & Probability \\
\hline LNRPCGDP & 4.123062 & 0.712033 & 5.790550 & $0.0000^{* * *}$ \\
\hline LNRDIR & 0.414597 & 0.178456 & 2.323247 & $0.0283 * *$ \\
\hline LNADR & 0.365293 & 0.141909 & 2.574147 & $0.0161 * *$ \\
\hline INFR & -0.003416 & 0.014369 & -0.237721 & 0.8140 \\
\hline LNBB & 0.728042 & 0.180290 & 4.038166 & $0.0004 * * *$ \\
\hline DTDUMMY & -1.045292 & 0.248861 & -4.200308 & $0.0003 * * *$ \\
\hline C & -16.782070 & 4.918796 & -3.411825 & $0.0021 * * *$ \\
\hline
\end{tabular}

Source: Results of Eviews-10, 2020.

Note: The $* * *$ and $* *$ sign indicate the significance of the coefficients at $1 \%$ and $5 \%$ significance level respectively

As the long run estimated result of the above table showed, level of real per capita GDP(RPCGDP) has a positive impact on private saving and statistically significant at 1 percent significance level. Since the growth model is specified in a level-log regression, the coefficients can be interpreted as a unit change with respect to level of real per capita GDP (RPCGDP). The coefficient of level of real per capita GDP (RPCGDP) is 4.123062 and this indicates that, in the long run, holding other things constant, a 1 percent change in real per capita income GDP brought 4.12 percent change in private savings during the study period. This result is in-line with the main assumption of private savings theories which is consistent with the Keynesian theory of absolute income hypothesis where per capita income is treated as an important driver of private saving. Moreover, our findings support the theory of Life Cycle Model, which posits that as the growth of income per capita increases, people 
tends to save more. Our findings go against Permanent Income Hypothesis, which posits that people consume more and save less when income increases. Previous studies that have been done on private saving also found the same result including the work of Kiptoo(2011), Epaphra (2014), Ayalew (2013) and Giancarlo et al. (1992). Thus, as the real per capita income of private agents grows faster, private saving also increases.

From the point of monetary policy, real deposit interest rate (RDIR) has a positive and significant effect on private saving. Therefore, the result is a positive coefficient of 0.414597 and statistically significant at 5 percent significance level. This result indicates that real deposit interest rate in the country during the study periods has a significant effect on private saving. As the result, a one percent increase in real deposit interest rate will result in 0.41 percent increase in private savings in the long run. The result is consistent with the life cycle theory when the substitution effect surpasses the income effect. Similarly, McKinnon and Shaw (1973) and Athukorala and Sen (2004) have argued that the relationship between real interest rate and saving is positive for a developing economy. It also consistent with empirical findings of Keho (2011), Horiokaet al. (2007) and N.Wachukwu (2012) stressed that real deposit interest rate has a positive impact on private savings.

Age dependency ratio (ADR) is also an important determinant of private saving. The result of age dependency ratio is statistically significant at 5\% significance level but its coefficient is 0.365293 , which is positive and not expected. This implies that a one percent increase in age-dependency ratio will lead to an increase in private saving by 0.365293 percent in the long-run. The unexpected positive coefficient result of age dependency ratio might be associated with the decline of age dependency ratio stars from the year 2003 up to now. Similarly, the increasing number of working age population in the country from year to year (reached to 60 percent in the year 2018/19) might be associated with a large amount of saving and a significant impact on Ethiopian economic growth. The statistical significant result of the study is consistent with the work of Doshi(1994), Tiriongo(2005) and Samuel(2005) of long-run ARDL model.

The general inflation rate, as shown in the above table has a negative impact on private saving, even though statistically insignificant. In the Ethiopian history, inflation remained at a reasonable low-level rate until 2002/2003.But after 2003/04, the inflation rate increased and reached 36.4 percent in 2009(NBE, 2018/19), which was caused primarily by food inflation and affect the well-being of the society than harming the macroeconomic performance. The insignificant effects of inflation on private saving might be associated with the reasonable low level (single digit) inflation rate until 2001/02(NBE, annual report 2018/19). Moreover, the result of this study also consistent with Heer\&Sussmuth(2006), Haile Ademe(2013) and Miller \& Benjamin(2008) as an average inflation registered 12.6 percent during the study period(2018/19). From the descriptive and econometric result, we can understand that inflation dose not harm the private saving significantly for the study period.

Number of bank branch (NBB) is positive and statistically significant at 1 percent significance level. This result suggests that to achieve maximum benefit and to promote private saving, number of bank branches or financial sector development is an essential instrument. In Ethiopia financial sector development associated with current bank branch expansion will have positive long run effect on private saving rate. This implies that the null hypothesis of number of bank branch has no effect on private saving was rejected and the alternative hypothesis was accepted. As the result, a one percent increase in the number of bank branch will result in 0.73 percent increase in private saving, which proves that the expansion of bank branches will result in reducing the cost of banking transactions and thus motivate private sector to save.

The long run, the drought dummy variable as (DTDUMMY) has a negative impact on private saving and statistically insignificant in the study period. Individuals increase precautionary saving in the face of increased uncertainty in the economic environment. An increase of one percent in inflation decreases private Savings by 1.05 percent over the long run period holding others constant.

Finally, the long run estimated model presented as follow with figures in the parenthesis indicates calculated tvalue.

$$
L N P S=-16.7821+4.1231 L N R P C G D P+0.4146 L N R D I R+0.3653 L N A D R-
$$

\subsection{INFR $+\quad 0.7280 \mathrm{LNBB}-1.0453 \mathrm{DTDUMMY}$

(-0.2377) (4.0382) (-4.2003)

1.12.5. Short Run Error Correction Model

After the acceptance of long-run coefficients of the growth equation, the short-run ECM model is estimated. The error correction term (ECM), as we discussed in chapter three, indicates the speed of adjustment to restore equilibrium in the dynamic model. It is a one lagged period residual obtained from the estimated dynamic longrun model. The coefficient of the error correction term indicates how quickly variables converge to equilibrium. Moreover, it should have a negative sign and statistically significant at a standard significant level (i.e. p-value should be less than 0.05 ). 
Table-8: Error Correction Representation for the selected ARDL (1, 3, 0, 0, 0, 1) Selected based on Akaike Information Criterion

\begin{tabular}{|c|c|c|c|c|}
\hline \multicolumn{5}{|c|}{ Dependent Variable is D(PS) } \\
\hline Regressors & Coefficient & Standard Error & t-Statistic & Probability \\
\hline D(LNRPCGDP) & 0.296539 & 0.266255 & 1.11374 & 0.2756 \\
\hline D(LNRPCGDP(-1)) & -1.469189 & 0.422058 & -3.481014 & $0.0018 * * *$ \\
\hline D(LNRPCGDP(-2)) & -1.476407 & 0.645275 & -2.288027 & $0.0305 * *$ \\
\hline D(LNRDIR) & 0.240894 & 0.114295 & 2.107658 & $0.0449 * *$ \\
\hline D(LNADR) & 0.361094 & 0.140071 & 2.577938 & $0.0160 * *$ \\
\hline D(INFR) & -0.003377 & 0.01414 & -0.238791 & 0.8131 \\
\hline D(LNBB) & 0.719672 & 0.196723 & 3.658297 & $0.0011 * * *$ \\
\hline D(DTDUMMY) & -1.033274 & 0.283097 & -3.649894 & $0.0012 * * *$ \\
\hline CointEq(-1) & -0.988503 & 0.147458 & -6.703638 & $0.0000 * * *$ \\
\hline \multicolumn{5}{|c|}{$\begin{array}{c}E C=L N P S-(-16.7821+4.1231 L N R P C G D P+0.4146 L N R D I R+0.3653 L N A D R-0.0034 I N F R+ \\
0.7280 L N B B-1.0453 D T D U M M Y) \\
\end{array}$} \\
\hline R-squared & 0.947341 & \multicolumn{2}{|c|}{ Mean dependent var } & 23.63746 \\
\hline Adjusted R-squared & 0.925062 & \multicolumn{2}{|l|}{ S.D. dependent var } & 1.940000 \\
\hline S.E. of regression & 0.531168 & \multicolumn{2}{|c|}{ Akaike info criterion } & 1.825000 \\
\hline Sum squared resid & 7.335631 & \multicolumn{2}{|l|}{ Schwarz criterion } & 2.341746 \\
\hline Log likelihood & -22.66765 & \multicolumn{2}{|c|}{ Hannan-Quinn criterion } & 2.008605 \\
\hline F-statistic & $42.52212[0.0000]$ & \multicolumn{2}{|l|}{ Durbin-Watson stat } & 2.527590 \\
\hline
\end{tabular}

Source: Results of Eviews-10, 2020.

Note: The $* * *$ and ${ }^{* *}$ sign indicate the significance of coefficients at $1 \%$ and $5 \%$ significant level respectively.

In table- 8 above, the error correction coefficient estimated at -0.988503 is highly significant, has the correct negative sign, and imply a very high speed of adjustment to equilibrium. In other word, the highly significant error correction term further confirms the existence of a stable short-run relationship.

Moreover, the coefficient of the error term $(\operatorname{ECM}(-1))$ implies that the deviation from long-run equilibrium level of private saving in the current period is corrected by $98.85 \%$ in the next period to bring back equilibrium when there is a shock to a steady state relationship.

The coefficient of determination(R-squared) is high explaining that about $92.5 \%$ of the variation in private saving is attributed to variations in the explanatory variables in the model. In addition, the value of DW statistic 2.53 does not suggest autocorrelation and the F-statistic is also quite robust.

The hypothesis related to real per capita GDP in the research hypothesis number one of chapter one for the relationship between real per capita GDP (RPCGDP) and private savings was analysed below.

$\mathbf{H}_{0}$ (Null Hypothesis): There is no significant relationship between real per capita income GDP and Private savings.

H1 (Alternative hypothesis): There is significant relationship between real per capita income GDP and Private savings.

From the above table- 8 , unlike to the long run effect, the result of RPCGDP in one and two periods lagged found negative impact on private saving, which is not expected but statistically significant at $1 \%$ and $5 \%$ significance level respectively in the short run. As a result, a one percent increases in real per capita GDP will result in 1.469189 or 1.476407 percent decrease in private savings in one and two periods lagged respectively. The result implies that in the short run (initial period of time),people in developing countries like Ethiopia consumes their entire income rather than saves. However, the result is statistically significant, the null hypothesis there is no significant relationship between real per capita income GDP and private savings was rejected. Moreover the result is consistent with Keynes' savings theories that in short run at very low levels of income as well as at zero income, since consumption is positive, savings must be negative. Similarly, Friedman's permanent income hypothesis $(\mathrm{PIH})$ states that changes in permanent income, rather than changes in temporal income are what drive the changes in a consumer's consumption patterns.

The hypothesis related to real deposit interest rate in the research hypothesis number two of chapter one for the relationship between real deposit interest rate (RDIR) and private savings was analysed below.

$\mathrm{H}_{0}$ (Null Hypothesis): There is no significant relationship between real deposit interest rate and Private savings. $\mathbf{H}_{1}$ (Alternative hypothesis): There is significant relationship between real deposit interest rate and Private savings.

As one can understand from the above table-4.8, real deposit interest rate (RDIR) is significantly affecting private saving during the study period. This implies the null hypothesis there is no significant relationship between real deposit interest rate and private savings was rejected. From this, we can understand that during the 
study period, in the short run, real deposit interest rate does have a significant positive impact on private savings. Similar to the long run, the result is significant at 1 percent significant level. As a result, a one percent increase in real deposit interest rate will result in an increase in private savings by 0.240894 percent in the short run.

This implies as deposit interest rate increases individuals are motivated to save their disposable income in the bank. The result is consistent with Ayalew(2013) in the short run.

The hypothesis related to age dependency ratio in the research hypothesis number three of chapter one for the relationship between age dependency ratio (ADR) and private savings was analysed below.

$\mathrm{H}_{0}$ (Null Hypothesis): There is no significant relationship between age dependency ratio and Private savings.

H1 $_{1}$ (Alternative hypothesis): There is significant relationship between age dependency ratio and Private savings.

In table-8 above the variable of age dependency ratio (ADR) is statistically significant, implies that the null hypothesis there is no significant relationship between age dependency ratio and private savings was rejected.

Similar to the long run effect, the result of age dependency ratio (ADR) variable in the short run is found to have a positive relationship with private savings, which is not expected and have a negative relationship with private saving. But it is significant at 5\% significance level. This implies that a one percent increase in agedependency ratio will lead to an increase in private saving by 0.361094 percent in the short-run. The unexpected positive coefficient result of age dependency ratio might be associated with the decline of age dependency ratio from year to year in the country and people are aware for the importance of savings. The result of age dependency ratio is same to the result of Masson et.al. Masson et.al (1998) concluded that the countries which have high ratio of working age population present high savings rate as compared to countries which have low ratio of working age population.

The hypothesis related to inflation rate in the research hypothesis number four of chapter one for the relationship between inflation rate (INFR) and private savings was analysed below.

$\mathbf{H}_{0}$ (Null Hypothesis): There is no significant relationship between Inflation rate and Private savings.

H1 (Alternative hypothesis): There is significant relationship between Inflation rate and Private savings.

On the other hand, inflation of goods and service is still insignificant in the short run like the long run effect, with a negative coefficient of -0.003377 , which indicates it is not contrary to economic theory, the negative relationship between inflation and Ethiopian economic growth. This implies that the impact of inflation dose not harm the private saving significantly for the study period. Therefore, the hypothesis that the null hypothesis there is no significant relationship between inflation rate and private savings was not rejected.

The hypothesis related to number of Bank branches in the research hypothesis number five of chapter one for the relationship between number of Bank branches (NBB) and private savings was analysed below.

$\mathrm{H}_{0}$ (Null Hypothesis): There is no significant relationship between number of Bank branches and Private savings.

H$_{1}$ (Alternative hypothesis): There is significant relationship between number of Bank branches and Private savings.

From the above table- 8 , similar to the long-run result, the result of number of bank branch (NBB) in the short term has positive impact (a coefficient of 0.719672 ) on private saving and statistically significant at 1 percent significance level. This implies the null hypothesis there is no significant relationship between number of bank branch and private savings was rejected. From this, we can understand that during the study period, in the short run, number of bank branch does have a significant positive impact on private savings. Therefore, a one percent increases in number of bank branch will result in 0.72 percent increases in private saving in the short run.

Moreover, the result of drought dummy variable as (DTDUMMY) is similar to the long run result have a negative impact on Ethiopian economic growth and statistically significant at 1 percent significance level in the short term. As a result, when there is drought in the economy, $1.03 \%$ decreases in private saving will occur in the short run. This result is consistent with the theory that when there is drought saving is low.

1.12.6. Summary of hypothesis testing

In the hypothesis of independent variables are statistically significant effects on dependent variable. This summary shows table below.

Table 9: Summary of hypothesis testing results

\begin{tabular}{|c|l|c|c|}
\hline H. No. & \multicolumn{1}{|c|}{ Hypothesis } & Value & $\begin{array}{c}\text { Results ofFinding } \\
\text { (Accepted / Rejected) }\end{array}$ \\
\hline $\mathbf{H}_{\mathbf{1}}$ & D(LNRPCGDP(-1)) & -1.469189 & Rejected \\
\hline $\mathbf{H}_{\mathbf{2}}$ & D(LNRDIR) & 0.240891 & Rejected \\
\hline $\mathbf{H}_{3}$ & D(LNADR) & 0.361094 & Rejected \\
\hline $\mathbf{H}_{\mathbf{4}}$ & D(INFR) & -0.003377 & Accepted \\
\hline H5 & D(LNBB) & 0.719672 & Rejected \\
\hline
\end{tabular}

Source: Taken from Eviews-10 result of table 8 short run error correction model

From the empirical result of the above long run and short run model of the study,itconclude that real per capita GDP (RPCGDP) (but unexpected negative sign in the short run), real deposit interest rate (RDIR), Age 
dependency ratio (ADR) (but unexpected positive coefficient sign in long and short run), number of bank branch (NBB) have significant effects on determinants of private saving. This implies that we rejected the value stated in the null hypothesis. However, inflation rate (INFR) has insignificant role on private savings and we accepted the null hypothesis.

\subsection{Findings}

The main objective of this study is to analyse the determinants of private saving in Ethiopia using time series annual data from 1978 to 2018. To determine the long run and short run relationship between the variables, Autoregressive Distribution Lag (ARDL) model was applied. Before applying the ARDL model, all the variables are tested for their time series properties (stationery properties) using the ADF and PP tests. As a result, private saving (PS), level of real per capita GDP (RPCGDP), age dependency ratio (ADR), and Number of bank branches (NBB) are stationery in first difference while real deposit interest rate (RDIR) and inflation (IFR) are stationery in level.

Next, to testing for time series property, the model stability was done by testing the diagnostic testing techniques. The result revealed that no evidence of serial correlation, no functional form problem (the model is correctly specified), the residual is normally distributed and no evidence of heteroscedasticity problem. As we discussed above, this study applied the methodological approach called ARDL model also known as bound test approach. As the result indicated the bound test (F-statistic) value is larger than the upper bound critical value both for Pesaranet al. (2001) and Narayan (2005), which indicates there is a long run relationship between privates saving and its determinants in long run during the study period.

The coefficient of determination(R-squared) is high explaining that about $92.5 \%$ of the variation in private saving is attributed to variations in the explanatory variables in the model. Moreover, the error correction term (ECM (-1)) appears with a negative sign and is statistically significant at $1 \%$ level, ensuring that the long run equilibrium can be attained. In addition, the Durbin-Watson statistic is about 2.53 which provide evidence of the absence of autocorrelation and the F-statistic is also quite robust.

The estimated parameters of the explanatory variables based on the specific objectives point out to below:

1.13.1. Effect of Real per Capita Income GDP on Private Savings

The empirical result showed that real per capita GDP (LNRPCGDP) has a positive and very significant impact on private saving during the study period in the long-run. This implies that a $1 \%$ increase in real per capita GDP (LNRPCGDP) results in $4.12 \%$ increase in private saving. Similarly, real per capita GDP (LNRPCGDP) has significant impact at a 1\% and 5\% significant level in one and two semi-annuals lag periods but negative effect on private savings in the short run, which is not expected. The result is consistent with the Keynesian theory of absolute income hypothesis and Friedman's life cycle hypothesis in which per capita income is an important driver factor of private savings.

\subsubsection{Effect of Real deposit interest rate on Private Savings}

It is found that real deposit interest rate (RDIR) has a positive impact on private saving and statistically significant at 5\% significance level in both the long and short run. This implies that a one percent increase in real deposit interest rate would result to 0.414597 and 0.240894 percentage point increase in private savings in both the long and short-run respectively. This result indicates that real deposit interest rate in the country during the study periods has a significant effect on private saving. It also consistent with empirical findings of Keho (2011), Horiokaet al. (2007) and N.Wachukwu (2012) stressed that real deposit interest rate has a positive impact on private savings.Effect of age dependency ratio on Private Savings

\subsubsection{Effect of age dependency ratio on Private Savings}

The result of age dependency ratio (LNADR) has a positive impact, which is not expected but statistically significant at $5 \%$ significance level in both long and short run periods. This implies that a one percent increase in age dependency ratio would result to 0.365293 and 0.361094 percentage point increase in private savings in both the long and short-run respectively. The unexpected positive coefficient result of age dependency ratio might be associated with the gradual decline of age dependency ratio and increasing number of working age population creates increasing the amount of saving in the country from year to year. The statistical significant result of the study is consistent with the work of Doshi(1994), Tiriongo(2005) and Samuel(2005) of long-run ARDL model.

\subsubsection{Effect of inflation rate on Private Savings}

However, the study found out that general inflation (INFR) has a statistically insignificant impact on private saving with a negative sign in the long run and short run periods. The insignificant effects of inflation on private saving might be associated with the reasonable low level or single digit inflation rate until 2001/02. This implies that the impact of inflation dose not harm the private saving significantly for the study period. Moreover, the result of this study also consistent with Haile Ademe(2013) and Heer\&Sussmuth(2006).

\subsubsection{Effect of number of bank branches on Private Savings}

Number of bank branch (NBB) hasfound a positive impact on private saving and very statistically significant at $1 \%$ significance level in both the long and short run. This implies that a one percent increase in bank branch 
would result to 0.728042 and 0.719672 percentage point increase in private savings in both the long and shortrun respectively. This result suggests that to achieve maximum benefit and to promote private saving, number of bank branches or financial sector development is an essential instrument.

\subsection{Recommendations}

Based on the finding of this study, the following policy recommendations are forwarded.

$>$ Real per capita GDP (LNRPCGDP) in our model is a key determinant of private saving; especially it has very significant impact on private saving in the long run. In order to enhance the contribution of the real per capita GDP, the government of Ethiopia has need to introduce policies such as reduce income inequality,promote growth of per capita income by improving productivity of workers and; improving and ensure stable and low inflation rates will help improve real incomes.

$>$ Likewise, real deposit interest rate has a positive and significant impact on private saving; a policy implication that is an increase in the real deposit interest rate will lead to a rise in private savings in Ethiopia. But to use interest rate as a means of increasing saving different measures should be taken first. This include: developing financial markets, deregulating the commercial sector including removing any ceilings on interest rate and increasing the participant in the financial sector.

$>$ Age dependency ratio (LNADR) has a positive sign, which is not expected but statistically significant on private saving. Therefore, government important policy recommendation would be focusing on improving the life expectancy, which in turn, would improve the dependency ratio. This would entail improvement of health care provision for the entire Ethiopian population. This partly will motivate workers to save for the old age.

$>$ Number of bank branch has a very significant positive impact on private saving. Therefore, the Federal Government of Ethiopia should give especial attentions to increases financial access throughout the country by further expanding bank branches and services because most of the bank branches concentrated on the urban area while majority of the population lives in rural areas with limited access to financial institutions. In addition to this increasing micro financing institutions is an important instrument to increase private saving because it easily reaches poor societies and enhances their saving behaviour.

In general, it can be pointed out that Ethiopian economy is largely depending on Agriculture, the income of most people is very low and it is from hand to mouth. So, in order to increase the level of individual income as well as saving rate it is recommended that government and policy makers should be focused on improving the economic growth that could increase high level of income. Lastly, Ethiopia needs to develop the habit of saving like that of China and decrease youth and old age dependency so as to use the full potential of 1.2 million people who enter active workforce group each year.

\section{REFERENCES}

Adewuyi, Bankole, \&Arawomo. (2007). What Determines Saving in the Economic Community of West African State (ECOWAS)? Journal of Monetary and Economic Integration, 71-72.

Agrawal, P. \& P. Sahoo\& R.K. Dash (2009). "Savings Behaviour in South Asia”,Journal of Policy Modelling, $31(2), 208-224$

Agrawal, P. (2001). "The Relation between Savings and Growth: Co-integration and Causality Evidence from Asia” Applied Economics, Vol. 33, 499-513.

Agrawal, P., Pravakar, S., \& Dash, R. K. (2010).Savings behaviour in India: Co-integration and causality evidence.The Singapore Economic Review, 55(02), 273-295.

Ahmad, Z. B. \& Marwan.T., A. (2003). Determinants of Gross National Savings in Malaysia: A Macroeconomic Analysis 1960-2000. Savings and Development, 27 (4), 421-440.

Ahmed, Salih Mustafa Mualley (2011). "Determinants of Savings: Empirical Evidence from African Countries, 1990-1999. The Academy of Islamic Fiqh - Sudan.

Ando, A., \& Modigliani, F. (1963). The Life Cycle Hypothesis of Saving: Aggregate Implications and Tests. American Economic Review, 53, 55-84.http://www.jstor.org/pss/1817129 Retrieved from http://www.jstor.org/pss/1817129.

Apunda, R. (2009).Determinants of Private Savings in Kenya.University of Nairobi press, 1-50.

Ashenafi, D.T, (2018).Impact of privatization on Economic Growth in Ethiopia.LAP LAMBERT Academic publishing.

Athukorala, P. and K. Sen (2004)."The Determinants of Private Saving in India", World Development, 32(3), pp. 491-503.

Athukorala, Prema-Chandra and SenKunal (2004).The Determinants of Private Saving in India, World Development, Vol.32, No.3, pp.491-503.

Ayalew Daniel (1995).Determinants of private domestic saving in Ethiopia, Unpublished MSc thesis, Addis 
Ababa University, Addis Ababa Ando A. and Modigliani F. (1963), the life cycle hypothesis of saving, American economic review, 53(1): 15-33.

Ayalew H.A. (2013).Determinants of domestic saving in Ethiopia: An autoregressive. Journal of Economics and International Finance, 5(6):248-257.

Bacha E. (1990). "A Three Gap Model of Foreign Transfer and the GDP Growth Rate in Developing countries",Journal of Development Economics 32(2).

Bankole, A. S., \&Fatai, B. O. (2013).Relationship between Savings and Economic Growth in Nigeria.MedwellJournals, 224-230.

Bosworth, B. \& G. Chodorow-Reich (2007). Saving and Demographic Change: The Global Dimension, available at SSRN: <http://ssrn.com/abstract=1299702> or $<$ http://dx.doi.org/10.2139/ssrn.1299702>, 28.01.2017.

Carroll, C.D. \& D.N. Weil (1994). "Saving and Growth: A Reinterpretation”, Carnegie-Rochester Conference Series on Public Policy, 40, 133-192.

Chopra, S. (1988).Inflation, Household Savings and Economic Growth.Ph. D. thesis.

Deaton, A. \&Paxson, C. (1993). Saving, Growth and Aging in Taiwan. Working paper No. 4330, 47. Retrieved February 26, 2013, from http://www.nber.org/papers/w4330.pdf?new_window=1

Deaton, A. (1989).Saving and liquidity constraints (No. w3196).National Bureau of Economic Research.

Deaton, A. (1997). The Analysis of Household Surveys - A Microeconomic Approach to Development Policy. Baltimore: John Hopkins University Press.

DeGregorio J. (1992).Economic Growth in Latin America,Journal of Development Economics, Vol. 39 , PP. 59 84.

Dornubsch R, Edwards S, Eds.The Macroeconomics of Populism in Latin America. Chicago: The University of Chicago Press; 1991.

Dosh, K (1994). 'Determinants of the saving rate: An International Comparison,' Contemporary Economic Policy, Vol.12, no. 1, pp. 37-45. 